\title{
MEDIA LITERACY TRAINING FOR SENIOR HIGH SCHOOL STUDENTS IN ADMINISTRATIVE VILLAGE OF RAWA BUAYA IN ADDRESSING PORNOGRAPHIC CONTENT ON YOUTUBE SOCIAL MEDIA
}

\author{
Nur Kholisoh \\ Universitas Mercu Buana \\ nur.kholisoh@mercubuana.ac.id
}

\begin{abstract}
Social media technology takes various forms such as internet forums, weblogs, and YouTube. The existing laws stipulate normatively that offensive content videos can only be watched for the registered users with the age limit of 18 years old. However, many senior high school children with the age limit of under 18 years old can access pornographic videos on YouTube social media. All this time many senior high school students as a millennial generation do not care about and understand negative content on social media, particularly those related to sexual harassment and pornography. In fact, not a few senior high school students still consider sexual harassment and sex as something taboo so that they never ask teachers and parents about healthy information on sex and sexual harassment. Therefore, it is necessary to build awareness and understanding on the danger of negative content on social media among senior high school students particularly YouTube social media so as to avoid negative impact of sexual harassment and pornography. This can be carried out through literacy activities for senior high school students as a millennial generation, in addressing pornographic impact on YouTube social media.
\end{abstract}

Keywords: Literacy, pornography, social media, students, YouTube

\section{INTRODUCTION}

The Administrative Village of Rawa Buaya is part of Cengkareng Sub-District in West Jakarta Administrative City with total land area of 27.93 square kilometers. It consists of six (6) Administrative Villages: West Cengkareng, Kapuk, Kedaung Kali Angke, Duri Kosambi, Rawa Buaya and East Cengkareng. Cengkareng Administrative City is not the location of Soekarno-Hatta International Airport geographically. There is misconception on the location of the international airport that it is located in the administrative city. In fact it is located in Benda Sub-District, Kota Tangerang. Therefore, it directly borders to Cengkareng as the transit place to the International Airport.

The Administrative Village of Rawa Buaya is former private land rights of Tan Liok Tiauw Sia, Landheer van Batoe-Tjepper, the landlord and the industrial pioneer during the Dutch East Indies. The administrative village approaches to Rawa Buaya Station and Rawa Buaya Busway Bus Stop. The Administrative Village of Rawa Buaya is the same as other administrative villages in Greater Jakarta, it has vision and mission as well. It becomes foundation to reach the objectives of residents of Administrative Village of Rawa Buaya. The vision of Rawa Buaya Administrative Village is : "Achieving BERSAHABAT in the Administrative Village of Rawa Buaya (Clean, Healthy, Harmonious, Safe, Faithful and Devoted to God Almighty)".

The mission of Administrative Village of Rawa Buaya is: (1) Providing excellent public services to residents in the Administrative Village of Rawa Buaya; (2) Constructing the sense of care and togetherness as well as increasing public participation to support the development of Greater Jakarta Province; (3) Increasing cleanness in the territory of Administrative Village of Rawa Buaya by giving the priority of the arranged, healthy, comfortable and healthy environment; (4) Designing and stimulating public empowerment activities that grows on the basis of public initiatives; (5) Trying to increase and create public order and comfortability; (6) Increasing the performance of apparatus of 
Administrative Village of Rawa Buaya so that public get the best, fast and right services; (7) Creating the harmony and tolerance in religious services.

Currently the spread of many pornographic websites occurs on social media including YouTube. Social media is an online media where users can participate and share information. It has the following characteristics: messages sent to many persons. The sent messages are free and without any Gatekeeper. It occurs faster than other media and those receiving the messages determine the time of interaction. Most of content on YouTube come from individual uploaders despite media companies like CBS, BBC, Vevo, Hulu upload their material to the website as part of their partnership with YouTube. The unregistered users can watch videos while the registered users can upload videos with the unlimited number. The existing laws stipulate normatively that the offensive content videos can be watched for the registered users with the age limit of 18 years old.

Therefore, in fact there are many children and adolescents with the age limit of under 18 years old, they can access porn videos on YouTube social media. Porn pictures on porn websites will attach on children's mind for long time so it is difficult to erase immediately. Technology is a media that can help humans to have a better life. If technology is misused, it can destroy their users. Internet as part of technology in information and facility access for communication, it can become beckfire if it is not used wisely. Based on the survey results, Indonesia occupies the seventh row that downloads the biggest porn films in the world. The porn website downloaders in Indonesia are mostly from youth, adolescents and under-age children. Most of the porn websites are downloaded through Internet cafe because they are afraid if their parents know what they do at home.

\section{METHOD}

The target of the community services is senior high school students in the Administrative Village of Rawa Buaya, Cengkareng Sub-District, West Java Administrative City. The reason to choose senior high school students is for the biggest social media users and those potential to be exposed to negative impact of pornography on social media, particularly YouTube.

The senior high school students are those with the age range of 16-18 years. Their development is appropriate to the phases of human development. However, time and rhythme in each aspect are not always similar. Moreover, senior high school students as a group of people learn in group or individual, they are psychologically in the unstable psychological condition during the process of finding their self. In such a condition, senior high school students are very vulnerable towards the influence of social environment including from social media.

The training uses some ways or methods, i.e. discussion, presentation and speech. The discussion occurs in form of Focus Group Discussion (FGD). It was carried out after the participants were divided into some small groups. They would discuss themes or issues that the speakers had conveyed particularly in relation to the impact of pornography on social media, particularly YouTube social media. After the discussion had been carried out, the representation of each group would presented the FGD results alternately. Moreover, other groups would give response and comment about the group's presentation. Moreover, the results of Focus Group Discussion (FGD) would be discussed with the speakers. They would give direction and explanation through speech. In the discussion, the speakers presented the main material on pornography and the negative impact of pornography on social media particularly YouTube social media. Moreover, they discussed about the Empowerment of Teachers and Parents' Attitude to prevent the negative impact of pornography on YouTube social media. For further explanation and better understanding about the presented materials, the speakers would give various examples in relation to pornography on social media.

\section{RESULT AND DISCUSSION}

Right now senior high school students use to access media per day greater than learning time. They watch television average three hours during school day and 7.4 hours on weekend. The amount of time to play electronic games reaches 3.8 hours and for Internet 2.1 hours per day in average. The data of Nielsen Media indicates one of four television watchers in Indonesia are children and they watch television for three hours per day in average (Hendriyani, et al. 2011:2012).

The impact of electronic media particularly social media towards senior high school students is 
relatively disappointing. Based on the data of Situs Komunitas Rawa Buaya, at least there are three crucial problems in relation to senior high school students, i.e. sexual harassment (40\%), drug uses $(17 \%)$ and adolescents fight (12\%). The problems closely relate to media consumption that senior high school students use in the territory of the Administrative Village of Rawa Buaya. The content on social media including YouTube is frequently inappropriate for the consumption of senior high school students.

Sexual harassment problem that occurs among senior high school students mostly gets influence from social media content including YouTube. All this time many parties do not care about healthy information about sex for children and adolescents. Many parents consider that sex is taboo so that they do not give healthy sex information for their children and adolescents. It occurs because they themselves have lack of information about sex and they do not know how to communicate good sex to their children. Therefore, when adolescents want to meet their great willingness to know about sex, they frequently search pornographic content through social media silently. They do it alone or with their friends.

In one week there are more than 4,000 porn websites produced, it is very concern. It is possible at first that children do not intend to open pornographic content. However, the porn websites can appear suddenly when they search information on their learning task or other information need. Children cannot clearly differ between bad and good website content, they with the age range of 8-12 years becomes the target. It is not surprising if sexual crime among adolescents and under-age children frequently occurs recently. Various negative impacts of watching porn films for under-age children is the destruction of mentality and morality and it has impact to sexual crimes, such rape, pregnant before marriage, venereal disease and other negative impacts. After they have negative watching habit, they want to make their own porn videos to record their sexual activities with their spouses.

When dating their relationship does not develop healthy. If individuals have pornography addiction, their spouse becomes sexual objectification like those they watch on porn websites. Moreover, in many cases, pornographic content makes them loss of their work power. Pornographic content can destroy sexual relationship with their spouses because they fantasize other people in sexual relationship. Imagination is a strong pornographic effect. Sexual value and purity indeed becomes destructive. Once children watch pornographic content, all pictures and scenes will be planted into their unconscious mind. It will bring them deeply and deeply. Right morality values will disappear gradually so that double standards will be confusing. Therefore, they will be far from spiritual activities. To overcome problems related to pornography on social media, particularly YouTube, socialization and literary should be carried out. It will build and increase the skill of senior high school students in Rawa Buaya in managing and understanding information on social media, particularly YouTube in relation to specifically pornography.

The definition of literacy in general is the quality of individuals to process and understand information when they reads or write. Indeed literacy is more than just writing and reading skill. In Merriam-Webster's online dictionary, the definition of literacy is quality or state of being "literate." In the definition, it includes writing and reading skill as well as skill to recognize and understand ideas conveyed visually (videos, pictures).

Education Development Center (EDC) states that literacy is an individual's quality to use all potential and skills they have in their life, and therefore, it is not only about reading and writing skill. Education and literacy quality are two very important things in our life. The advance of a country directly relates to the literacy level in the country.

Therefore, this community services activities are expected to give contribution to senior high school students, parents, the government and public in general about the danger and impacat of pornographic content on social media, particularly YouTube among senior high school students. The results of the community services activities can become inpurt for policy makers in making regulations and laws as effort to prevent and handle the impact of pornographic content on social media particularly towards senior high school students. In fact recently it frequently occurs.

Moreover, the media literacy activities should be carried out so that senior high school students in the Administrative Village of Rawa Buaya may have skill to process and understand information and content on social media positively. In this matter, the intended information is related to information on pornography on YouTube social media.

Before presenting the training results on "Literacy For A Millennial Generation, Senior High School Students in Addresing Pornography on YouTube Social Media", two weeks before the execution, 
the team met with Headman (Lurah) of Rawa Buaya to present the purposes and objectives of the training activities. The meeting results agreed that the training would be carried out on Tuesday, March 20, 2018 at RPTRA Hall of the Administrative Village of Rawa Buaya.

In the execution of the training, there were 30 senior high school students surrounding the Administrative Village of Rawa Buaya having been invited. The training went on successfully and smoothly. Moreover, the presentation of Literacy for a Millennial Generation of Senior High School Students was presented. Dr. Nur Kholisoh, M.Si as the executor of the training activities presented it. Before the presentation, she showed the social media platform, such as Path. Twitter, Instagram, Facebook, YouTube and Vlog. After the presentation, she explained about the impacat of YouTube social media positively and negatively.
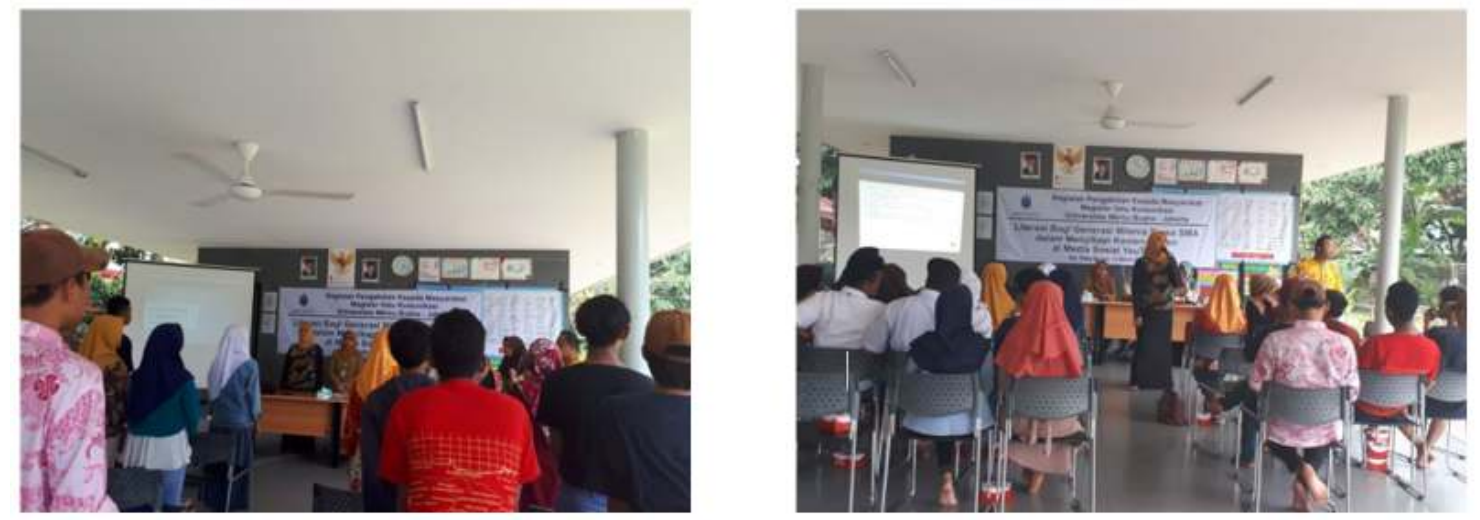

Figure 1 and 2. The State of Training

To strengthen the explanation for the danger and negative impact of social media, particularly YouTube, she presented the danger and negative impact of pornography on YouTube as shown in the following figures :
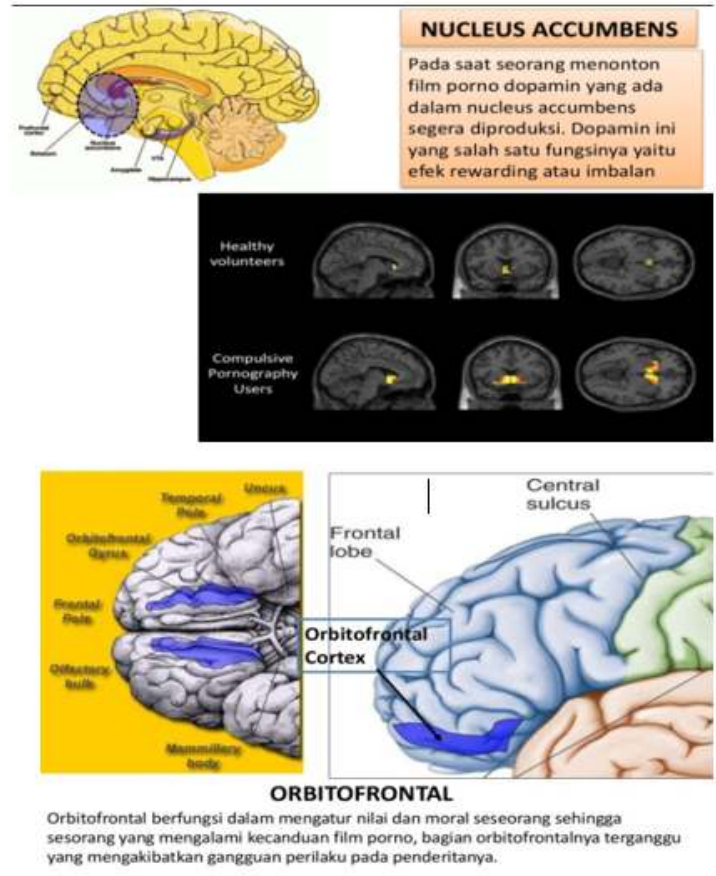

Figure 3 and 4. Explanation on Danger of Pornography 
There are some way of preventing negative impact of social media content, including YouTube. These include : (1) the Supervision of Parents. Parents have to supervise their adolescents including their senior high school students in activities related to Internet, particularly the uses of social media. Moreover, they have to pay attention to the consumption of social media among their children. Don't let them consuming media with negative content such as pornography. Despite Ministry of Information Technology and Communication has blocked pornographic websites, such websites still develop. Therefore, parents should supervise their adolescents particularly when they access Internet. (2) Socializing Wise Uses of Social Media, it is expected to prevent senior high school students from the negative impacts of Internet uses. If Internet is used with full responsibility, senior high school students will get benefit when they accomplish their learning tasks. The senior high school students have to address ethics and avoid racism content. Moreover, don't give personal data in detail on social media because it can trigger potential criminal action particularly when they download video content or pictures of immoral offenses.

Moreover, she also presented alternative solution on the handling of pornography addicts having been carried out in USA, i.e. the special school for pornography addicts in Oxbow Academy, Utah, USA. The school is the pioneer school to cut the pornographic addiction for adolescents in USA. Parents of the students in USA who consider that their children are in pornography addiction can enter their children into the school.
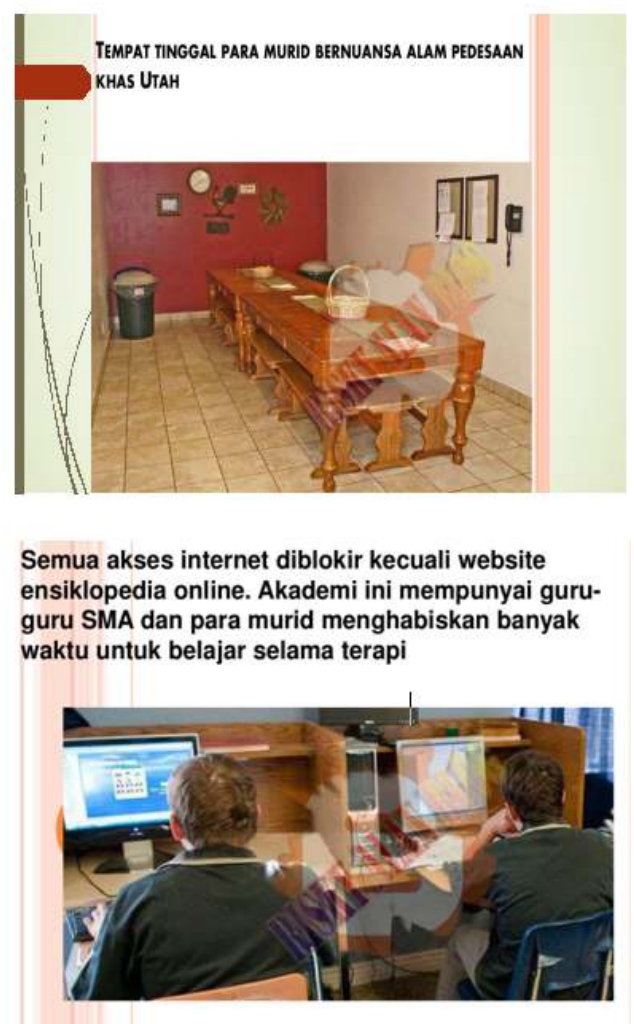

Figure 5 and 6. Oxbow Academy in Utah, USA

In the question answer session, the participants ask various questions in enthusiasm. They ask about reasons why Indonesia occupies the second world ranking country that access pornographic content in the world. Moreover, they also ask about the possibility for Indonesia to establish schools like Oxbow Academy. 


\section{CONCLUSION}

Conclusion from the training include (1) YouTube social media has positive and negative impact. However, the negative impact is stronger if we do not use it wisely. There are some negative impacts of YouTube social media, such as the frequent distraction of physical and psychological health, social isolation from neighborhood, lack of time to spend with family, forgetting to take care of themselves, depression and dependence, the reduction of productivity and social sense; (2) The training participants can accept explanation clearly and understand the presentation materials correctly. After the participants get explanation and training, they become more focus on positive points of YouTube social media, and they try to have wise attitude towards the danger of pornography on YouTube social media.

Concerning the suggestion from the research, parents and or teachers should supervise children/their educated children frequently so that they can avoid the negative impact of pornography on YouTube social media. Besides supervision, parents and or teachers carry out the frequent socialization activities on the uses of YouTube social media wisely.

\section{REFERENCES}

Arifin, A. (1988). Ilmu Komunikasi: Sebuah Pengantar Ringkas. Rajawali Press.

Devito, J. A. (1997). Komunikasi antar manusia. Jakarta: Professional Books.

Fahrudin, A. (2011). Pemberdayaan partisipasi dan penguatan kapasitas masyarakat. Bandung: Humaniora.

Lord, J., \& Hutchison, P. (2009). The process of empowerment: Implications for theory and practice. Canadian Journal of Community Mental Health, 12(1), 5-22.

Mc. Quail, Dennis Sven Windhal, (1996) Communication Models, Longman Inc, USA

Mulyana, D. (2000). Ilmu komunikasi: suatu pengantar. Remaja Rosdakarya.

Paul, R. Wayne, J Don F, (2000) Komunikasi Organisasi, Remaja Rosdakarya, Bandung.

Sendjaja, S. D. (1993). Pengantar Komunikasi: Materi Pokok Ikom 4130/3sks/modul 1-9..

Sulistyani, A. T., \& Wulandari, Y. (2017). Proses Pemberdayaan Masyarakat Desa Sitimulyo Kecamatan Piyungan Kabupaten Bantul Dalam Pembentukan Kelompok Pengelola Sampah Mandiri (KPSM). Jurnal Pengabdian Kepada Masyarakat (Indonesian Journal of Community Engagement), 2(2), 146-162.

Wilonoyudho, S. (2009). Model Pemberdayaan Masyarakat Dalam Pengendalian Banjir Yang Berwawasan Lingkungan Di Kota Semarang (Communities Empowerment Model in Managing the Floods in Line with Environmental Conception in Semarang (City)). Jurnal Manusia dan Lingkungan, 16(2), 81-90. 